\title{
CULTURES AND LANDSCAPES OF THE UPPER KAMA REGION IN THE EARLY HOLOCENE
}

(C) 2017

Lychagina Evgenia Leonidovna, candidate of historical sciences, associate professor of Ancient and Middle History of Russia Department Perm State Humanitarian Pedagogical University (Perm, Russian Federation)

Zaretskaya Natalia Evgenievna, candidate of geological and mineralogical sciences, senior researcher of Isotopes Geochemistry and Geochronology Laboratory

Geological Institute of Russian Academy of Sciences (Moscow, Russian Federation)

Chernov Alexey Vladimirovich, doctor of geographical sciences, professor, leading researcher of Soil Erosion and Riverbed Processes Research Laboratory

Lomonosov Moscow State University (Moscow, Russian Federation)

Demakov Denis Alexandrovich, master student of Ancient and Middle History of Russia Department Perm State Humanitarian Pedagogical University (Perm, Russian Federation)

Mitroshin Evgeny Nicolaevich, senior engineer of History, Archaeology and Ethnography Department Perm Scientific Center of Ural Branch of Russian Academy of Sciences (Perm, Russian Federation)

Abstract. The following paper gives a description of the landscapes formed in the Upper Kama basin in the Holocene. First of all, the authors describe the first river terraces and the most ancient floodplain generations. In the Upper Kama basin, 35 Mesolithic sites are known. During the mapping of the study area, 3 micro regions were identified with a large concentration of Mesolithic settlements and territories with early unknown Holocene sites. The first group includes: the area of the upper Kama near the village of Liokmartovo-Kazantsevo, the old-channel formation of Chashkinskoye Lake and the lower stream of the river Kosa. The second one is the Upper Kama in the Gainy and Kosinsky districts of the Perm region. The analysis of the Mesolithic sites locations showed dependence of the first terraces on the most ancient floodplains of large water arteries. At the same time, this dependence should not be exaggerated because people often settled on smaller rivers and streams.

Keywords: Upper Kama; Mesolithic; archaeological sites; palaeochannel analysis; floodplain generation; floodplain terrace; root bank; radiocarbon analysis; Holocene; short-term site; base camp.

УДК 902.034/902.3

Статья поступила в редакцию 18.05.2017

\section{HOW TO MAP SUBMERGED STONE AGE SITES USING ACOUSTICS (SOME EXPERIMENTAL RESULTS)}

(C) 2017

Grøn Ole, researcher of Department of Geosciences and Natural Resource Management

University of Copenhagen (Copenhagen, Kingdom of Denmark)

Boldreel Lars Ole, doctor, associate professor of Department of Geosciences and Natural Resource Management

University of Copenhagen (Copenhagen, Kingdom of Denmark)

Hermand Jean-Pierre, professor of Acoustics \& Environmental Hydroacoustics Laboratory

Université libre de Bruxelles (Brussels, Kingdom of Belgium)

Rasmussen Hugo, engineer

Danish Nitro-Electro (Copenhagen, Kingdom of Denmark)

Dell'Anno Antonio, doctor, associate professor of Department of Life and Environmental Sciences

Università Politecnica delle Marche (Ancona, Italian Republic)

Cvikel Deborah, doctor, researcher of Leon Recanati Institute for Maritime Studies

University of Haifa (Haifa, State of Israel)

Galili Ehud, doctor

Israel Antiquities Authority (Atlit, State of Israel)

Madsen Bo, candidate of sciences

Museum of Eastern Jutland (Randers, Kingdom of Denmark)

Nørmark Egon, head of laboratory of Department of Geoscience

Aarhus University (Aarhus, Kingdom of Denmark)

Abstract. A central problem for maritime archaeology has been to find survey methods that facilitate efficient and precise mapping of Stone Age sites on the seabed down to the lowest sea level (approximately - $140 \mathrm{~m}$ ) during glacial periods, as well as sites embedded in sea-floor sediments. As predictive landscape modelling has proved to be inadequate for this task, a different approach based on direct detection is required. The observation of an acoustic phenomenon associated with man-made flint debitage - but not naturally cracked pieces of flint - has opened a window for development of an alternative and efficient direct mapping method. This paper discusses the development of the idea, as well as experimental documentation of the principle on which it is based. It includes a preliminary analysis of how far away on each side of the transducer flint debitage emits an acoustic response, and consequently the required distance between sailing lines for a comprehensive survey to be undertaken at a specific depth.

Keywords: Maritime archaeological survey methods; high-resolution seismics; subbottom-profiling; chirp technology; marine acoustics; acoustic damping; geo-acoustic layer characterisation; resonance phenomena; submerged Stone Age sites; flint knapping technology; interdisciplinary studies. 


\section{Introduction to flint debitage resonance}

Flint knapping is a popular activity among Stone Age archaeologists, and is a good basis for a better understanding of the lithic tools they excavate, describe and analyse in their work. The archaeological literature describes the reduction of a core by flint knapping as the controlled removal of sharp pieces of debitage. More specifically, a shock wave (created for example with a hammer stone) is used to release the so-called Hertzian cone phenomenon, thereby removing a section conjoining a Hertzian cone running approximately parallel to the side of the core [1]. However, sound appears also to play a part in this process.

This latter sonar element of flint knapping is not yet fully understood, even though it is under investigation. Acceptance of the full consequences of it, however, appears to provide a method for direct mapping of submerged Stone Age settlements that avoids the methodological problems of predictive modelling and can even detect sites embedded in the sea-floor sediments [2-4].

In 1980, Grøn observed a strong resonance phenomenon associated with flint knapping. As it is flint (predominantly) and other silicate minerals knapped by humans that define the term 'Stone Age', this was of potential interest for mapping of Stone Age sites. Especially so, if it could also be used to detect debitage embedded in, and thereby damped by, sediments. He therefore asked Rasmussen, who had links with the Bang and Olufsen (B\&O) sound laboratory, to analyse some pieces of knapped flint debitage to discover whether they had any interesting acoustic properties [5].

In 1982, 16 knapped flint 'blades' and 'flakes' from nine different Stone Age sites in Denmark were analysed by Rasmussen and others in the B\&O sound laboratory. The resonance from these pieces proved to be so strong that the pieces had to be damped during the experiment not to damage the receiver. The promising preliminary conclusions of these laboratory analyses were that:

- flint debitage knapped by humans responds acoustically (like a tuning fork) when excited with an appropriate acoustic signal within the interval $3-20 \mathrm{kHz}$;

- flint debitage should respond in a similar way to appropriate acoustic signals even though it is embedded in a damping sediment, and it should be possible to detect this response.

Major acoustic-research environments outside the B\&O laboratory, however, rejected the archaeological usefulness of the observed resonance phenomenon, citing problems resulting from the damping effect of surrounding sediments. The project was consequently shelved till 2010, when Grøn and Hermand met within the framework of the SPLASHCOS project (EU COST Action TD0902). Hermand, who became involved at an early stage in the relatively new discipline 'geoacoustic layer characterisation', agreed that it was time to give the old idea another chance. The discipline focusses on the acoustic characterisation of submerged geological layers on the basis of acoustic properties of the elements they contain. It seems obvious to attempt to detect an element such as resonating lithic debitage by acoustic means $[6 ; 7]$.

In 2011 Grøn and Boldreel began a collaboration on development of methodology for the mapping of archaeological features buried in sea-floor sediments based on high-resolution sub-bottom profiling. While it was possible to detect embedded poles, shipwrecks and other similar features, and the application of high-precision navigation made it quick and easy after the survey for divers to locate and verify or reject the observed recorded anomalies without having to open up larger excavations, mapping of Stone Age sites represented a problem. It had been demonstrated that Stone Age cultural layers could be identified in the sub-bottom profiles. The problem was that it was impossible to distinguish between 'artificial' Stone Age cultural layers and natural geological layers in the records [8; 9].

The solution appeared to be to attempt to develop a system that employed the debitage resonance phenomenon, if the efficiency and effectiveness of this could be further underpinned by experimental data.

\section{Finite element modelling}

In the Acoustics and Environmental Hydroacoustics Laboratory at The Free University of Brussels (ULB), Hermand and some of his $\mathrm{PhD}$ students have developed a realistic 3D digital model of a piece of seabed consisting of several geological layers for the purposes of finite element modelling (FEM). This is a way of mimicking physical processes in a digital space divided into extremely small spatial units with physical propertied matching those in the real world: density, elasticity, heat conductivity, etc. In this case, the major advantage was that high-resolution digital models of flint debitage could be implanted in the sea-floor sediments and removed again without disturbing the sediment layers. As a consequence, the sea floor's responses to different acoustic signals, when different pieces of flint debitage were embedded in it, could be modelled without disturbing, and thereby changing, the sediment stratigraphy. The results of the modelling exercises could therefore be directly compared. In the 'real physical world', the insertion and removal of debitage would have disturbed the layers such that the experimental results were not be comparable [7].

The downside is that finite element modelling is time consuming because of the data capacity required. In this case, one 3D modelling takes one day to run, even though a super computer is used. But control over the details and comparability of the results compensate for this. The process can also run without a human operator, so the operator time required is significantly less than the processing time.

The 3D finite element modelling produced results that strongly support the existence of the pronounced resonance phenomenon detected in the $\mathrm{B} \& \mathrm{O}$ sound laboratory. Significant resonance peaks are evident for single pieces within the same frequency interval as found in the sound laboratory (fig. 1). This confirms that acoustic responses can be expected from flint debitage embedded in water-saturated sea-floor sediments, and that - according to the model - a single piece of debitage can produce such a response $[6 ; 7]$.

\section{The experiment at Skovshoved Harbour}

To test the flint debitage resonance phenomenon in a real-world setting, Boldreel and Grøn, under the auspices of the Department of Geosciences and Nature Resource Management, University of Copenhagen, carried out several experiments [2]. We shall here report the results of one carried out off Skovshoved Harbour, north of Copenhagen.

A $12 \mathrm{~m}$ long line of samples, marked by the blue line in figure 2, was placed on the seabed, at water depths of between 7 and 7,5 m. A $6 \mathrm{~m}$ long stocking of plastic net 
was filled with flint debitage and placed on the seabed, extending from the eastern end of the blue line in figure 2 and $6 \mathrm{~m}$ to the WSW. It contained less than $1 \mathrm{~kg}$ of How to map submerged Stone Age sites using acoustics..

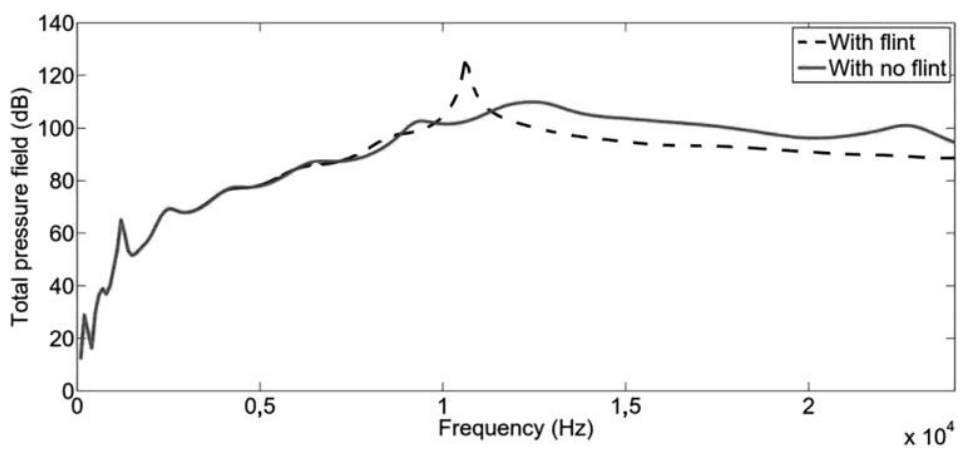

Figure 1 - Prediction of the total pressure field resulting from the insonification of a flint blade embedded $5 \mathrm{~cm}$ into a cultural layer. The simulated acoustic source and hydrophone are placed above the seabed, symmetrically about the flint piece, with an incidence angle of $5^{\circ}$. The sea-floor model consists of thin layers of sand and mud overlying the cultural layer, a thin underlying sand layer and moraine substrate. The red curve is the returned signal spectrum with no flint embedded in the cultural layer, while the black curve is the spectrum with a flint blade embedded. The resonance frequency is $10,6 \mathrm{kHz} .15$ [7]

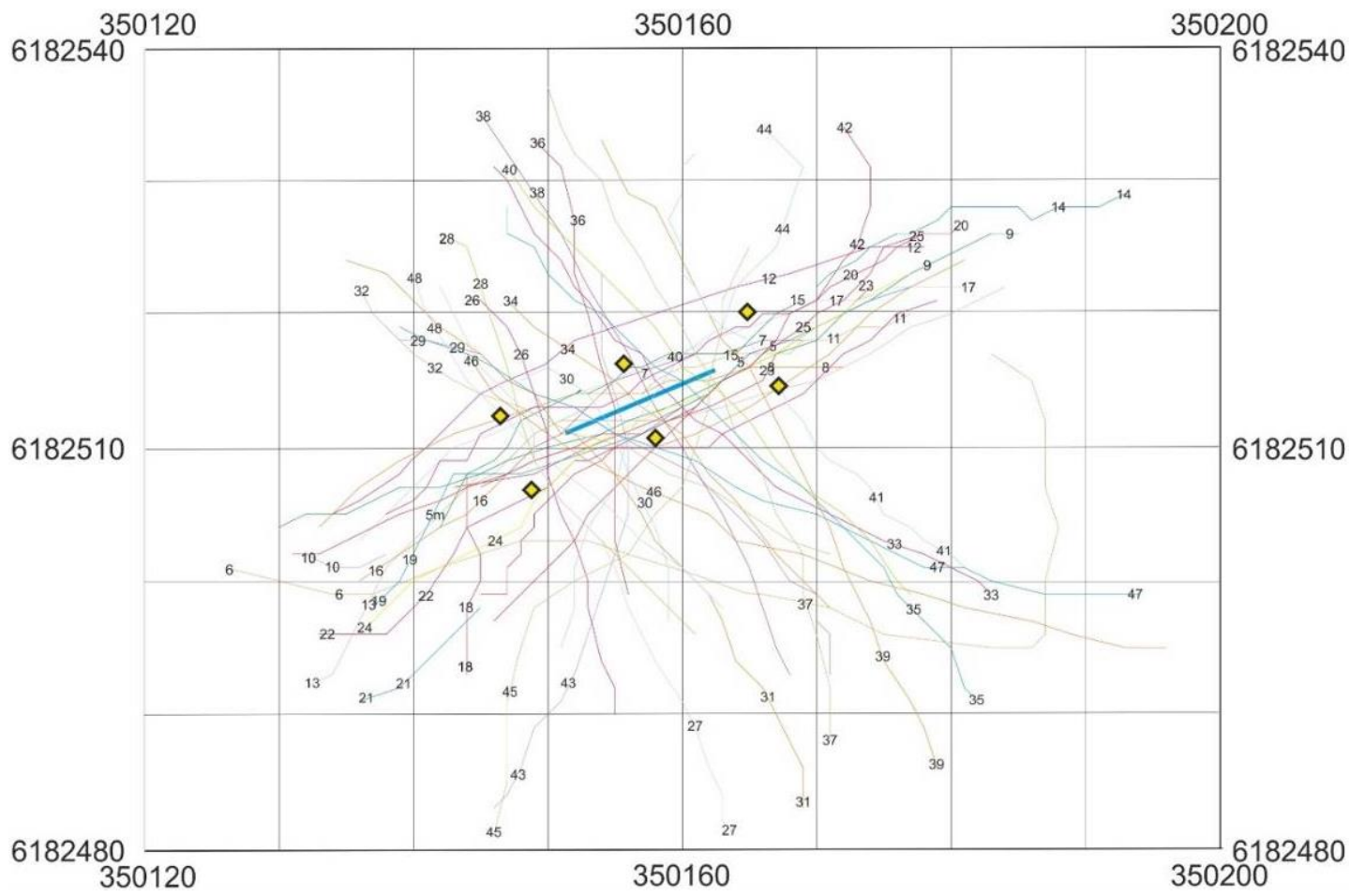

Figure 2 - The 48 sailing lines at the experimental site off Skovshoved Harbour.

The $12 \mathrm{~m}$ long blue line marks the position of the linear string of samples placed on the seabed. The six yellow rectangles mark the buoys used to control the boat's approach to the target. Coordinates in UTM zone 33

The stocking was divided into six sections which, from the east, contained the following: sample 1: 15 small flakes (fig. 3A), sample 2: 15 blades, sample 3: 15 blades, sample 4: 36 blades (fig. 3B), sample 5: 36 blades, sample 6: 72 flakes (fig. 3C). Furthermore, three bags containing lithic debitage of different types were placed, $2 \mathrm{~m}$ apart, on the seabed to the WSW on the blue line in Figure 2. Nearest to the stocking was sample 7, a bag containing very large flakes (fig. 3D), then sample 8 , a bag containing axes, and then sample 9, a bag containing cores. The aim of the two latter was to enable study of the acoustic response from knapping products that had very limited or no ventral surfaces preserved.

Before the samples were placed on the seabed, the area was checked for possible anomalous acoustic features, such as responses from unrecorded submerged Stone Age sites, gas pockets etc., which could disturb the recordings from the artificial target. Our experience is that acoustic responses from true ancient man-made features and structures, are a potential problem for controlled experiments in Danish waters, where the number of submerged Stone Age sites in some areas can be overwhelming. For instance, during experiments in the artificial lagoon of Amager Strandpark, east of Copenhagen [2], significant localised acoustic responses of the type produced by flint debitage, were recorded in locations where one could expect to find submerged Mesolithic sites or Mesolithic material dumped together with the material used to construct the lagoon barrier. These anomalies have not been verified by us, but we have passed their positions on to the appropriate museum authority. Well preserved Stone Age cultural layers were actually found during the maritime archaeological evaluation of the area prior to construction of the artificial lagoon, but these were not excavated [10]. 

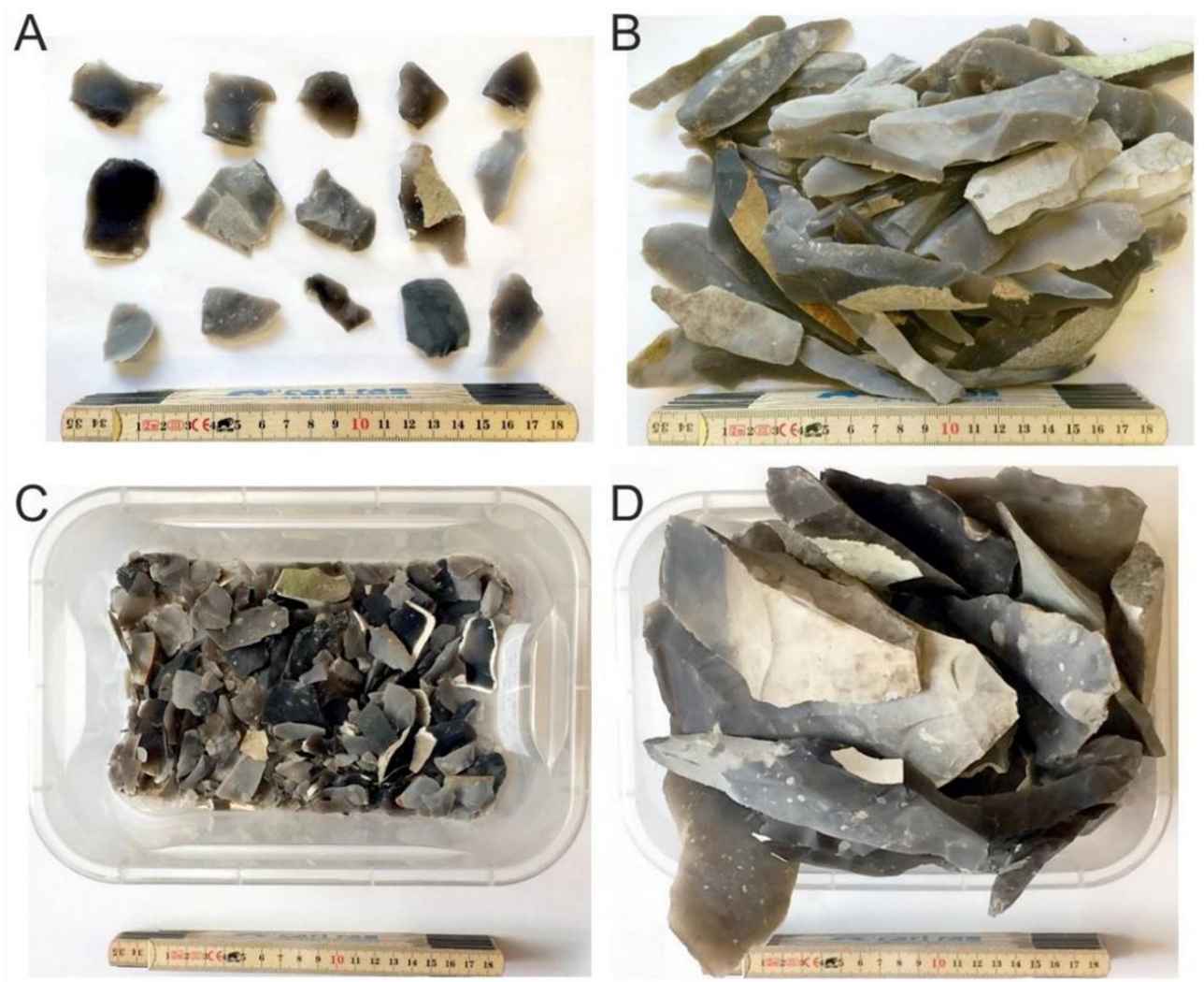

Figure 3 - Examples of the flint debitage samples placed on the seabed in the experiment. $A$-sample $1, B$-sample 4, $C$-sample 6, $D$-sample 7

One aim of this experiment was to attempt to obtain an understanding of differences in the acoustic responses arising from different categories and amounts of debitage. Problems with communication to the calibration source that should have enabled a navigation precision as high as $\pm 10 \mathrm{~cm}$, however, made it difficult to relate the individual samples to specific responses from the individual sections of the stocking or the individual bags.

The experiment produced a series of records of identifiable acoustic responses from the flint debitage and ar- tefacts placed on the seabed. This demonstrates that flint debitage produces an acoustic response to specific types of acoustic signal. These responses were, however, not as distinct and significant as those recorded at actual Stone Age archaeological sites with greater densities of flint debitage (fig. 4). But they are interesting because they demonstrate that rather ordinary settlement debitage densities can produce responses that are recordable with the present acoustic set-up.

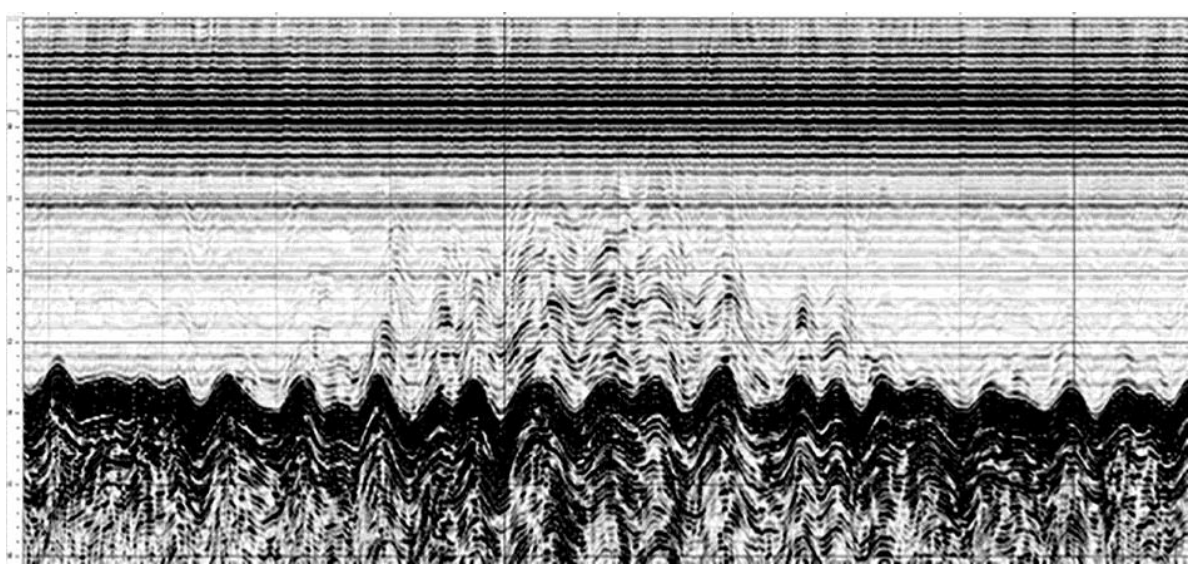

Figure 4 - Record of significant acoustic haystack features at the submerged Stone Age site at Atlit-Yam, Israel

The density of flint debitage in the area where the stocking was placed was not extreme relative to the norm for a Stone Age settlement. This experiment therefore indicates that it should be possible to detect a reasonable proportion of actual submerged Stone Age settlements using the existing preliminary acoustic set-up. Our experience suggests that detection should still be unproblematic even when these remains are covered by up to $1-1,5 \mathrm{~m}$ of sediment. We have no reliable experi- ence of detecting deeper-lying material and potential adjustment of the signal to obtain a response from this.

What is clear from the results we obtained is that the target must be no more than c. 3-4 $\mathrm{m}$ to one side of the transducer at this depth for it to respond: Line 38 (fig. 5) runs perpendicular to the line of targets. It produces a response 'haystack' that is c. $7 \mathrm{~m}$ wide, tallest in its central 2-3 $\mathrm{m}$ and declines steeply at each side. This sideways acoustic response is also a factor that makes it difficult to isolate different responses from samples located as close 
Grøn O., Boldreel L.O., Hermand J.-P., Rasmussen H., dell'Anno A., et al.

together as in this experimental design. This is one of the

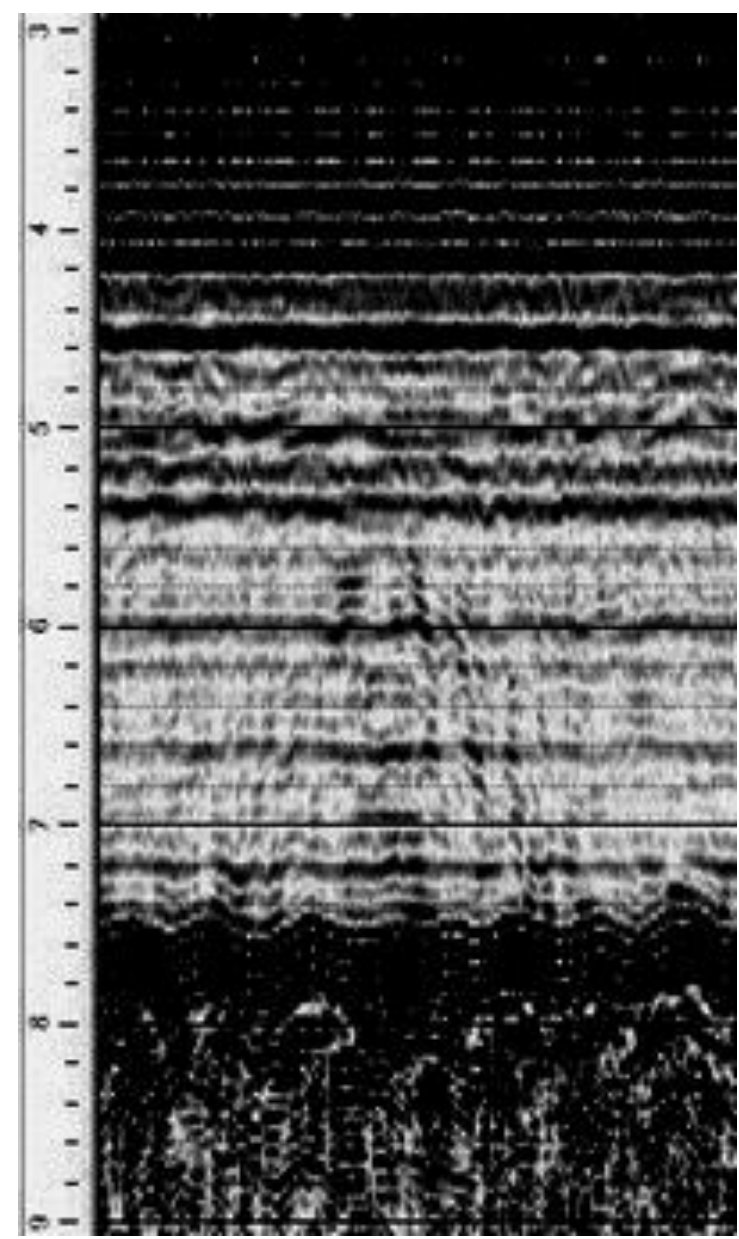

Figure 5 - Line 38 cutting across the line of targets resulting in an acoustic response that is approximately $7 \mathrm{~m}$ wide at its base

Line 13 (fig. 6) runs parallel with the line of targets from ENE to WSW and records a response over $7 \mathrm{~m}$, from the first to the last peak. Unfortunately, the low precision of the navigation does not permit identification of which samples are producing which responses. A significant variation in the height of the haystack phenome- positive results of this experiment.

non can be observed, which must be related to the variation in the samples. It is, however, impossible to relate this variation to specific samples.

\section{Discussion}

The Skovshoved experiment confirmed that flint debitage responds to specific acoustic signals. It is encouraging that such low concentrations of flint debitage, as used in this experiment, can produce recordable acoustic responses. This, in turn, means that it should be possible to detect a large number of submerged Stone Age sites using the technique at its present state of development.

The fact that the acoustic responses from flint debitage recorded here and in several other cases, from experimental targets or from known submerged Stone Age sites, are evident as 'haystack' features predominantly in the water phase seems to be because they represent delayed responses to the emitted signals from which they originated. This appears to reflect an interesting aspect of the physical properties of flint debitage knapped by humans, which is currently being investigated.

The Skovshoved experiment was not able to reveal a simple relationship between amount/density, type and size of the debitage pieces on the one hand and acoustic response features on the other. It did reveal, however, that an acoustic response can be obtained from a target at water depths of 7 to $7,5 \mathrm{~m}$, with transducer positions up to 3-4 $\mathrm{m}$ to one side of the target, equivalent to an angle of approximately $25-30^{\circ}$. Further experiments investigating the maximal distance between sailing lines that permits total coverage of the seabed at specific depths would be useful in relation to future routine surveys.

The results obtained here underpin the potential practical exploitation of a strange acoustic phenomenon that is only evident in flint debitage and not in naturally cracked flint [2]. They indicate that a better solution can be found to the problem of mapping submerged Stone Age sites, including those located at depth and embedded in sediment, than that currently available.

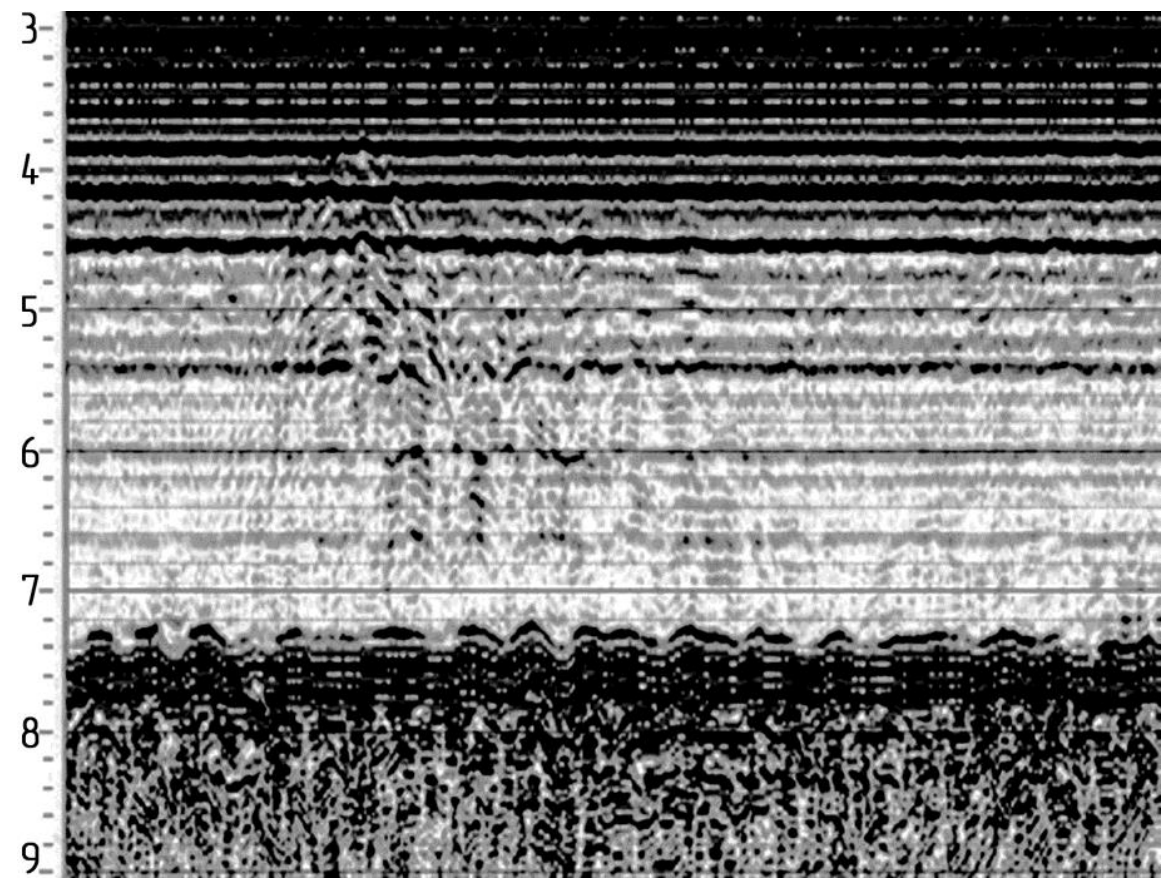

Figure $\mathbf{6}$ - Line 13 running parallel to the line of targets showing a difference in the height of the 'haystack' feature 
Acknowledgements. The survey was conducted with the aid of engineer Peer T. Jørgensen and two professional divers, Paul Christiansen and Per Freiberg, of the Department of Geosciences and Nature Resource Management, University of Copenhagen.

\section{REFERENCES:}

1. Knapp W.R. Some Talk About Angles / (ed.) M. Lynn, Flint Knapping. Articles, Tips, and Tutorials from the Internet. 3rd Edition. 2010. P. 163-164.

2. Grøn et al. - in prep.

3. Grøn O. Our grandfather sent the elk - some problems for hunter-gatherer predictive modelling. Quartär 59. 2012. P. 175-188.

4. Grøn O. The «fishing-site model» - a method for locating Stone Age settlements under water, or the opposite? // Norwegian version published in Norsk Maritimt Museum, Årbok 2014. P. 235-244.

5. Rasmussen H. Unpublished report on the acoustic resonance characteristics of flint debitage. 1982.
6. Hermand J.-P., Grøn O., Asch M., Ren Q. Modelling flint acoustics for detection of submerged Stone Age sites. Proc. OCEANS'11 MTS/IEEE Kona Conf. (Oceans of Opportunity: International cooperation and partnership across the Pacific), Institute of Electrical and Electronics Engineers, IEEE, Sept. 2011. 9 p.

7. Hermand J.-P., Tayong R. Geoacoustic characterization of Stone Age cultural layers: Preliminary FE modelling. OCEANS - Bergen, 2013 MTS/IEEE, 6 p.

8. Grøn O., Nørgård Jørgensen A., Hoffmann G. Marine Archaeological Survey by High-Resolution SubBottom Profilers. Norsk Sjøfartsmuseum, Årbok. 2007. P. 115-144.

9. Grøn O., Boldreel L.O. Chirping for Large-Scale Maritime Archaeological Survey: A Strategy Developed from a Practical Experience-Based Approach. Journal of Archaeology Volume 2014, Article ID 147390. 11 p.

10. Dencker J. Marinarkæologiske Forundersøgelser. Amager Strandpark NMU j.nr. 2322 \& Italiensvej NMU j.nr. 2322. Nationalmuseets Marinarkæologiske Undersøgelser. 2004.

\section{КАРТИРОВАНИЕ ЗАТОПЛЕННЫХ ПАМЯТНИКОВ КАМЕННОГО ВЕКА ПРИ ПОМОЩИ АКУСТИКИ (НЕКОТОРЫЕ ЭКСПЕРИМЕНТАЛЬНЫЕ РЕЗУЛЬТАТЫ)}

(C) 2017

Грён Оле, доктор наук, научный сотрудник

кафедры наук о Земле и управления природными ресурсами

Копенгагенский университет (2. Копенгаген, Королевство Дания)

Бордрел Ларс Оле, доктор наук, доцент

кафедры наук о Земле и управления природными ресурсами

Копенгагенский университет (2. Копенгаген, Королевство Дания)

Херманд Жан-Пьер, профессор лаборатории акустики и гидроакустики окружающей среды

Брюссельский свободный университет (2. Брюссель, Королевство Бельгия)

Расмуссен Хюго, инженер

Дейниш Нитро-Электро (г. Копенгаген, Королевство Дания)

Делль Анно Антонио, доктор наук, доцент кафедры наук о жизни и окружающей среде

Политехнический университет Марке (2. Анкона, Итальянская Республика)

Цвикель Дебора, доктор наук, сотрудник Института морских исследований им. Леона Реканати

Университет Хайфы (г. Хайфа, Государство Израиль)

Галили Ехуд, доктор наук

Израильское управление древностей (2. Атлит, Государство Израиль)

Мадсен Бо, кандидат наук

Музей Восточной Ютландии (2. Рандерс, Королевство Дания)

Нормарк Эгон, начальник лаборатории отдела наук о Земле

Орхусский университет (г. Орхус, Королевство Дания)

\footnotetext{
Аннотация. Одной из центральных проблем морской подводной археологии является поиск методов археологической разведки, которые позволили бы эффективно и точно проводить картирование памятников каменного века, находящихся на морском дне вплоть до глубин, соответствующих самому низкому уровню океана на протяжении периода последнего оледенения (около -140 м), а также памятников, перекрытых донными морскими отложениями. Поскольку предиктивное моделирование ландшафтов оказалось неподходящим для решения этих задач, потребовался иной подход, основанный на непосредственном обнаружении археологических объектов. Выявление акустического феномена, связанного с продуктами расщепления кремня человеком, - но не с кусками кремня, получившимися в результате естественного растрескивания, - открыло путь для развития альтернативного и эффективного метода картирования археологических объектов. В настоящей статье представлено обсуждение развития этого подхода, а также результаты экспериментов в отношении базовых принципов, на которых данный подход основан. Статья включает предварительный анализ дальности действия акустического прибора, позволяющей получить сигнал от расщепленного кремня, и, соответственно, того, какая дистанция должна быть выдержана между закладываемыми разведочными трансектами для получения полноценных результатов подводной археологической разведки в зависимости от определенной глубины.

Ключевые слова: методы разведок морской археологии; высокоточные сейсмические наблюдения; стратиграфия морского дна; технология звуковых импульсов; морская акустика; затухание акустических сигналов; геоакустическая характеристика слоев; явление резонанса; затопленные памятники каменного века; технология расщепления кремня; междисциплинарные исследования.
} 